\title{
Entrepreneurial Creativity: Sources, Processes and Implications
}

\author{
Valentina Della Corte ${ }^{1} \&$ Giovanna Del Gaudio ${ }^{1}$ \\ ${ }^{1}$ Department of Economics, Management, Institutions, University of Naples Federico II, Naples, Italy \\ Correspondence: Valentina Della Corte, Departement of Economics, Management, Institutions, University of \\ Naples Federico II, Naples, 80126, Italy. E-mail: giovanna.delgaudio@unina.it \\ Received: March 23, 2017 \\ Accepted: April 27, 2017 \\ Online Published: May 17, 2017 \\ doi:10.5539/ijbm.v12n6p33 \\ URL: https://doi.org/10.5539/ijbm.v12n6p33
}

\begin{abstract}
Literature on entrepreneurial creativity has been widely developed in the last decades, with attention both to the process and to its origins and antecedents. The aim of this paper is to systematize the literature on the topic, in order to better clarify the concept of entrepreneurial creativity in its main features and components.

The issue still shows rather fragmented contributions on the concept of entrepreneurial creativity in different disciplines, within a very complex multidimensional construct. Therefore, we propose a literature review whose main purpose is to get to an overview of the state-of-art on entrepreneurial creativity and to identify still unanswered issues within this stream of research.
\end{abstract}

Keywords: entrepreneurial creativity, literature review, sources, processes, implications

\section{Introduction}

\subsection{Entrepreneurial Creativity}

Creative entrepreneurship is like an overall process of creation, both in front of opportunities and threats and with reference to firm's resources, their combinations and changes.

Part of the literature regards the relationship between the entrepreneur and the external context, underlying his capacity of catching opportunities that other cannot see or see later (Fillis \& Rentschler, 2010). Some scholars concentrate on the resource use and bundling, which enlarge the number of options and the chances of innovating. Others underline that creativity is often stimulated by penurious starting contexts, since this represents an incentive to find new solutions (Shwartz \& Bless, 1991). Other contributions focus on the tools (social ties, social networks' connections) the entrepreneur can implement to get access to new resources that could be useful for creative development (Fillis \& Rentschler, 2010).

Some works try to systematize the main contributions on the theme, considering the main components of creativity (Dayan et al., 2013), its development (Zhou, 2008) and the methods to measure it (Sullivan and Ford, 2010).

However, the issue still shows fragmented contributions on the concept of entrepreneurial creativity in different disciplines, within a very complex multidimensional construct. Therefore, we propose a systematic literature review with an analysis to verify whether substantial differences exist in terms of academic debate on specific research themes and among methodological, theoretical and empirical studies.

\section{Definition of Entrepreneurial Creativity}

The definition of entrepreneurial creativity needs to take into account two precise terms, creativity and entrepreneurship, that already are expression of unique peculiarities. Their merge can give back the conceptual meaning of this expression. In the light of this observation, the current paper starts from the analysis of these terms to after achieve a definition suitable for the purpose of this work.

Some of the most cited definition of creativity in the works on entrepreneurial creativity is that of Amabile et al. $(1996,2000$, p. 368) and Sternberg (1999). The formers define creativity as the 'production of novel, useful ideas or problem solutions'; the latter as 'the ability to produce work that is both novel, i.e., original and unexpected, and appropriate, i.e., useful'. Coming back in 1942, Schumpeter used the expression "creative destruction" to emphatize the influence of entrepreneurial creativity and innovation on the creation of new products, services and organizations. More precisely, through creative distruction the entrepreneur 'reforms or revolutionizes the 
pattern of production ... and re-organize[s] an industry' (1942, p. 67).

Indeed, the creative distruction springs out for the dyad entrepreneur and innovation. This concept was used by Schmpeter to stress the importance on how creative destruction favours the stage of capitalism as a new stage of development. Hence, the economic growth is possible trough this creative destruction (Schumpeter, 1942) that refers to macroeconomic environment.

Furthermore, new entrants and other exogenous shocks (Schumpeter, 1942; Phan et al., 2010) are fundamental in this process since they are "agents of change" (Carnahan et al, 2010 p. 278) for the innovative activity.

From these definitions, novelty and usefulness emerge as the key elements of creativity (Sternberg, 1999). In other words, "to be creative, the solution to a problem must meet two criteria: it must be new and it has to solve the problem in question" (Sternberg, 1999, p. 182). Both elements are of foundamental importance but require an effective completion. Indeed, although an indea can be novel, the acceptance in the market in terms of commercialization is at the basis of the real novelty. On the other side an useful idea can be already applied and, hence, it does not produce value for the firm.

Hence, thaking into account other scholars (Perry-Smith \& Coff, 2011) we agree that novelty is "the extent an idea is unusual or unique" and usefulness is "the feasibility of an idea".

Another important question is "Why creativity is connected with entrepreneurship and how entrepreneurial creativity can be defined"?

Literature on creativity is attributed to employees (George \& Zhou, 2007; Gong, Huang \& Farh, 2009), managers (Scratchley \& Hakstian, 2001), entrepreneurs, etc. According to some authors creativity is the soul of entrepreneurship (Hornsby et al., 2002) and especially in dynamic context it is one of the key ingredient to successfully compete (Zhou, 2008; Mambula \& Sawyer, 2004). According to others (Block et al., 2013), creativity-driven entrepreneurs are more risk inclined rather than necessity-based entrepreneurs.

Previous works on entrepreneurial creativity tend to firstly define the term "creativity" to after contextualize it in the specific topic of entrepreneurship (Zhou \& Georg, 2001).

Some authors define entrepreneurial creativity as a complex phenomenon (Phan et al., 2010) that recalls both intrinsic and extrinsic motivations (Amabile, 1997). Others (Goss et al, 2007; Fillis \& Rentschler, 2010; Fortwengel et al, 2016), instead of defining "entrepreneurial creativity" put the attention on creativity as a component of entrepreneurial process that encourages the entrepreneur on catch/create opportunities from which benefit the competitive advantage. However, these definitions do not clarify how and to what extent creativity entrepreneurial creativity acts on opportunities as well as what are the main focuses of entrepreneurial creativity. This is the reason why this paper proceeds with a systematic literature review in order to verify the state of art of this topic.

Table 1. Definition of entrepreneurial creativity

\begin{tabular}{|c|c|c|}
\hline Author/s & Year & Definition \\
\hline Amabile & 1997 & $\begin{array}{l}\text { Entrepreneurial creativity requires a combination of intrinsic motivation and certain kinds of extrinsic } \\
\text { motivation - a motivational synergy that results when strong levels of personal interest and } \\
\text { involvement are combined with the promise of rewards that confirm competence, support skill } \\
\text { development, and enable future achievement. } \\
\text { The generation and implementation of novel, appropriate ideas to establish a new venture (a new } \\
\text { business or new program to deliver products or services). The primary novel, useful ideas may } \\
\text { have to do with: (a) the products or services themselves, (b) identifying a market for the products or } \\
\text { services, (c) ways of producing or delivering the products or services, or (d) ways of obtaining } \\
\text { resources to produce or deliver the products or services. }\end{array}$ \\
\hline $\begin{array}{l}\text { Lee, Florida } \\
\text { and Acs }\end{array}$ & 2004 & $\begin{array}{l}\text { Entrepreneurship is form of creativity and can be labelled as business or entrepreneurial creativity } \\
\text { because often new businesses are original and useful. }\end{array}$ \\
\hline Goss et al & 2007 & $\begin{array}{l}\text { Creativity is an important component of the entrepreneurial process (Ardichvili, Cardozo and Ray, } \\
\text { 2003; Goss et al 2007; Schumpeter, 1942), it is not a synonym for entrepreneurship. Creativity is } \\
\text { required for idea generation, but not all novel and useful ideas qualify as entrepreneurial } \\
\text { opportunities. }\end{array}$ \\
\hline Phan et al & 2010 & $\begin{array}{l}\text { Entrepreneurial creativity is a complex phenomenon that includes cognitive processes, individual } \\
\text { motivation, knowledge and personality, individual and team decision making, and social and }\end{array}$ \\
\hline
\end{tabular}




\begin{tabular}{|c|c|c|}
\hline & & economic influences \\
\hline & & $\begin{array}{l}\text { Creativity, as the cognitive process of discovering new patterns or combinations from familiar ideas, } \\
\text { routines, and mental models is thus the engine that drives entrepreneurial discovery. }\end{array}$ \\
\hline $\begin{array}{l}\text { Fillis and } \\
\text { Rentschler }\end{array}$ & 2010 & $\begin{array}{l}\text { Creativity enables the entrepreneur to act on these opportunities in ways which can result in } \\
\text { competitive advantage for the organisation. It can provide the basis for innovation and business } \\
\text { growth, as well as impacting positively on society generally. }\end{array}$ \\
\hline $\begin{array}{l}\text { Shepherd and } \\
\text { Patzelt }\end{array}$ & 2011 & $\begin{array}{l}\text { Since entrepreneurship is about the introduction of new and often original products, processes, and } \\
\text { services, researchers have emphasized the important role creativity plays in the entrepreneurial } \\
\text { process. }\end{array}$ \\
\hline Dayan et al & 2013 & $\begin{array}{l}\text { Entrepreneurial creativity can thus be seen as the capabilities of entrepreneurs to conceive of new } \\
\text { combinations of hitherto independent elements so that an improved or new product/service, process } \\
\text { or practice is formed, which adds value over what existed previously in the marketplace or in the } \\
\text { production environment. }\end{array}$ \\
\hline Block et al & 2013 & $\begin{array}{l}\text { Entrepreneurs who value the creativity associated with their ventures should also have a higher } \\
\text { willingness to invest in their ventures. }\end{array}$ \\
\hline Frodeman & 2014 & $\begin{array}{l}\text { The terms creativity and entrepreneurship are inherently inter- and transdisciplinary in academic } \\
\text { parlance, yet many recognize that they are actually postdisciplinary areas of study and practice that } \\
\text { converge and also redistribute disciplinary content within sociocultural contexts. }\end{array}$ \\
\hline Sardana & 2015 & $\begin{array}{l}\text { Entrepreneurship should then be seen as a creative element of the society that manifests itself in a } \\
\text { variety of forms, such as social, cultural, technical, political, or ecological. }\end{array}$ \\
\hline
\end{tabular}

Source. Our elaboration.

\section{Methodology}

In order to better clarify the examined topic, we proceeded with a literature review on the field. The first step was an extensive search through bibliographic electronic databases, and precisely: Business Source Premier (EBSCO), Emerald, Direct (Elsevier), and Google Scholar, matching then the results.

The outcomes of this search descend from a series of parameters, ex ante established, that are:

- Keywords search "creativity + entrepreneurship", "creative entrepreneur", "creative entrepreneurial capabilities", "entrepreneurial creativity";

- Selection of academic journals dealing with the following areas: strategic management, human resource management, strategic human resource management, psychology, sociology, organizational behavior and marketing.

Table 2. Keywords

\begin{tabular}{ll}
\hline & \\
\hline KW1 & entrepreneurial creativity \\
KW2 & creative entrepreneur \\
KW3 & creative entrepreneurial capabilities \\
KW4 & creativity + entrepreneurship \\
\hline
\end{tabular}

Source: Our elaboration.

Therefore, we selected the articles which better match the parameters, eliminating the contributions with close but different topics (id: employees' creativity, leadership, etc).

The obtained contributions have been systematized according to the focus, the objective and the adopted methodology. Our methodology recalls previous studies (Brady and Allen, 2006; Zain et al., 2001), that consider papers based on Case Study, Comparative analysis, Survey, Theoretical with Application methods.

We proceeded as follows. We built a first Pareto diagram on two co-ordinates: the number of publications and their categories in order to visualize the literature trends; we developed a second diagram according to the adopted methods. We singled out the top five journals for each research area. We then grouped the selected articles according to their main stream of research, main focus (process, antecedents, affective/cognitive factors, development and components) and explored relationships between research areas and research topics (social networks, bisociation, opportunities, etc.) in order to understand if there are recurring links or uncovered themes. 
Besides, we noticed a breakdown on both ontological and epistemological aspects of the debate on entrepreneurial creativity. We therefore pinpointed some streams of research on the topic, with different perspectives.

\section{Discussion}

The evolution of the theme of entrepreneurial creativity needs to be understood according to different point of views. The first refers to a descriptive analysis that explains the time evolution of the topic of entrepreneurial creativity in terms of number of published papers. This allows to understand when this topic has started to receive attention from the academic world and how it has evolved over the years. The second regards an analytic examination of the topic in order to understand how much progress has been done by scholars in this field, the possible changes and advances over the time in terms of contents, and the related mechanisms of evolution.

In the light of these observations, an analysis of the literature trends constitutes the starting point for both descriptive and analytic examination.

Figure 1 shows the literature trends from the year 1984 till 2016. A part from "Socialism, capitalism and democracy", the seminal work of Schumpeter (1942), where the concept of "creative destruction" comes out, Gilad (1984) represents a trailblazer with his work "Entrepreneurship: the issue of creativity in the market place" because he claims the necessity of an interdisciplinary perspective between psychology and economy for the analysis of the topic of entrepreneurial creativity. From the end of the ' $80 \mathrm{~s}$ and during the decade of the 1990s, the literary production is fairly scarce. In these contributions the issue of creativity is dealt with as one of the main characteristics (Jurčová, 1996), and it concurs to the formation of entrepreneur's profile (Winslow and Solomon, 1988). Indeed, these papers explain how entrepreneurship and creativity (Nyström, 1993) are related.

During the lapse of time 2003-2010, the literary trend starts to show some peaks in 2003 (five papers), 2004 (six papers) and 2008 (12 papers). Hence, the academic debate not only is expanded but also proceeds in depth with some related topics, such as the link between entrepreneurial creativity and the importance of social networks (Shalley et al, 2008; Florida and Acs, 2004) and the opportunity identification and development (Antonites and van Vuuren, 2014; Ardichvili et al., 2003).

The period 2011-2016 demonstrates a prosperous literary production with two main peaks in 2011 (nine papers) and in 2015 (fourteen papers). These contributions show a widening of the construct "creativity and entrepreneurship". Indeed, it becomes a solid construct in order to analyse other interrelated topics, such as business opportunities (Gielnik et al 2014) and creative interactions in social networks, or it finds application in some specific fields as in the case of entrepreneurship education (Hrotic, 2014; Hattab, 2014; Rahman and Day, 2015).

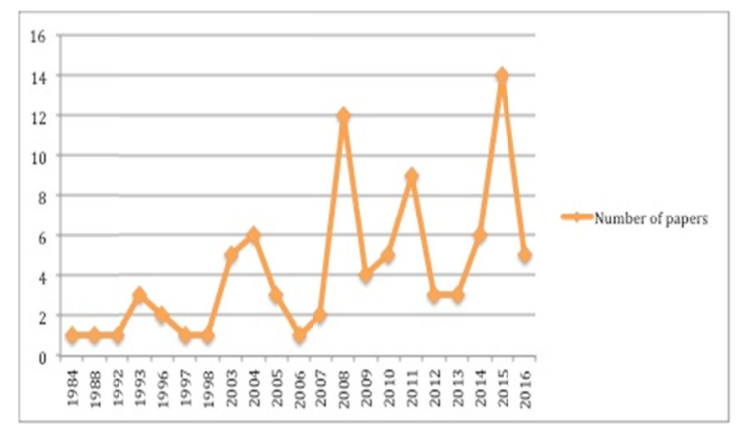

Figure 1. Literature trends

The second step of this literature review consists in the identification of the main focus of analysis in the selected papers. We identify four main areas of entrepreneurial creativity: process, antecedents, affective/cognitive factors and components. The choice on these precise points is the output of two different activities. The first regards an ex-ante analysis of the papers in order to find a connection between the topic of entrepreneurial creativity and the main focus of the paper; the second refers to a debate with a panel of fifteen worldwide strategic management scholars in order to identify the main variables for the literature review analysis.

Figure 2 shows the relationship with the topic of entrepreneurial creativity and the main focus of the analysed papers. The literature review demonstrates that $52 \%$ of the papers concentrate the attention on the process, the $23 \%$ on the antecedents, the $15 \%$ on the cognitive/affective factors and the $10 \%$ on the main components of the 
entrepreneurial creativity.

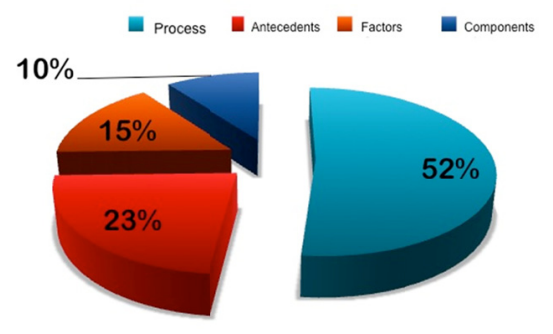

Figure 2. Main focus of the analyzed papers

More precisely, 61 contributions focus on the process of creativity, defining this latter as a "process characterized by a sequence of actions: identification, preparation, response generation, validation and communication, mainly based on the problem solving approach" (Csikszentmihalyi, 1996).

Anderson et al (2009) analyses, in particular, three levels of creativity: the thinking phase, the sculpting phase and the social or collective creativity (Fillis and Rentschler, 2010).

Combining personalities and process studies, Mahoney and Michael (2005) identify individual creativity, opportunities' discovery, surprise and learning as key factors in a "subjectivist theory of entrepreneurship".

The above set of contributions is interesting in linking the phase of idea generation with its implementation. Two main aspects come out: creativity is not generated at will (apart from situations of necessity in which the entrepreneur finds out genius solutions to problems) and it is not necessarily a linear process, because often facing ambiguity and uncertainty (Dasgupta, 1994).

As regards the issue of uncertainty, Perry-Smith and Shalley (2003) state "creativity can be used to deal with the ambiguity and uncertainty in decision-making by matching the nonlinear responses of the entrepreneur to that of the business world". While uncertainty refers to a lack of information, ambiguity refers to the existence of multiple and conflicting interpretations regarding an organisational situation (Kijkuit and Van-den-Ende, 2007). Such contributions are not sufficiently supported by empirical investigations: entrepreneurial creativity calls for implementation and commercialization in order to be profitable.

Another part of the analysed papers (27) focuses the attention on the antecedents to creativity. Tang (2016) finds that personal turbulence, that "refers to unusual, rapid, and agenda-setting events" (Tang, 2010) can influence entrepreneurial creativity. According to some scholars (Shapero, 1975), negative turbulence has a wider impact on entrepreneurial creativity rather than positive because in this situation entrepreneurs are more motivated to take actions and to be creative.

What is interesting to notice is the fact that there are two different schools of thought about the influence of external environment of entrepreneurial creativity. Some scholars (Schumpeter, 1942; Phan et al, 2010; Baron and Tang, 2011) assert that turbulent and difficult contexts stimulate entrepreneurial creativity; while others (Eckhardt and Shane, 2003) find that stable environments can facilitate entrepreneurial creativity because the level of uncertainty is lowest.

Dayan at al. (2003) identify four antecedents of entrepreneurial creativity: resource access, resource possession, expertise and creativity-self efficacy.

Resource access and resource possession are external factors that constitute the antecedents of entrepreneurial creativity because they constitute the real base for the creation of something new. The individual factors influencing entrepreneurial creativity are the expertise and creativity-self efficacy. The former allows to faster gain creative entrepreneurial solutions and the latter shows the entrepreneurial ability in performing creative outcomes. Other scholars (Fillis and Rentshler, 2010) identify factors belonging to the social/relational sphere, as antecedents of creativity, able to contribute to the creative entrepreneurial process. Hence, the whole decision making process is considered the precursor of creativity (Blauth, Mauer and Brettel, 2014).

Gap 1.1: Although literature demonstrates systematization's efforts of contributions focusing on antecedents of 
entrepreneurial creativity (Woodman and Shoenfeldt, 1990; Baluth et al., 2014; Amanile, 1996, 2013), the proposed models look at one or more antecedents without looking at the entire set of sources of entrepreneurial creativity that can belong to individual, organizational and social level. Literature is more developed on the individual and social level and wider analysis is needed according to organizational level of analysis.

Hence, the analysed antecedents show a lack an "interactionist model" (this term was coined by Woodman and Shoenfeldt in 1990 in order to express existing interactions among social, personality, cognitive, psychology and other perspectives), that simultaneously considers individual, organizational and external factors according to a pluralist lens of analysis (psychological, social, entrepreneurial, behavioural, etc.).

Gap 1.2: Literature demonstrates different views on the importance of external context on entrepreneurial creativity. This specific issue needs to be more developed according to both theoretical and empirical perspective. While contributions on the link between dynamic and turbulent environment and entrepreneurial creativity are developed, literature suffers of papers focusing the attention on the influence of stable environment on entrepreneurial creativity. Furthermore, in order to understand the these dichotomic behaviours (creative and not creative) according to different environmental situations, literature has to explore whether and to what extent the behaviours of entrepreneurs operating in the same industry can differ even in the condition of the same environmental situations. In the light of these observations, comparative studies can help in this understanding.

With reference to cognitive-affective factors in strategic decision-making, many scholars (Amabile, 2005; Bratnicka and Bratnicki, 2013) underlined their importance, but empirical research is still scarce.

Entrepreneurs implement cognitive processes to generate, validate, and refine ideas for new products, processes, or services (Gemmel et al., 2012). The probability of novelty "varies with the number of cognitive elements available for association and with the breadth of those elements that are treated as relevant to the problem" (Amabile, 2005). Cognitive processes such as divergent thinking and flexibility are critical to generate a rich set of alternatives to consider (Shalley and Perry-Smith, 2008).

Creativity entrepreneurship calls for high levels of cognitive creativity, generating a willingness to absorb and bear uncertainty: if entrepreneurs lack this capability, they are unlikely to use their cognitive capabilities to look for opportunities (Butler et al., 2010). Dayan et al. (2013) state that creative self-efficacy helps individuals enhance certain cognitive skills, such as greater memory recall and greater information searches.

Recently, Delgado-Garcìa et al. (2012) underline that "positive affective traits" can limit the entrepreneur's cognitive capacity and even reduce his motivation to think in a more elaborate way" and implement a simplified decision-making strategy. Negative emotional states, on the other hand, increase the entrepreneur's motivation to engage in more detailed and substantive process (Schwarz, Bless, 1991). On the contrary, George et al. (2007) state that positive affect promotes flexibility and creativity in thinking and is conducive to creativity and to the generation of new and useful ideas. Gap: Therefore, there is a lack of clearness in the identification of the ideal environment in which entrepreneurial creative behaviours can come to light. Furthermore, various scholars (Dijkesterhuis and Meurs, 2006; Perry-Smith, 2006) underline that when an individual is consciously working on a task, he/she may be limited in considering alternative creative plans of action: the mental set of schemes and assumptions can block his/her creative nature.

As regards the components/dimensions of entrepreneurial creativity divergent thinking (Runko, 2004; Davidsson and Honig, 2003) is considered a dimension of entrepreneurial creativity. Indeed, the entrepreneurial ability to afford multiple cognitive paths and to have divergent ideas can generate creative solutions. In this sense, creativity comes out when two or more ideas or pieces of information, that in the early stage appears separate, are then directed together for the generation of something new. In this process, combination and reorganisation are the two distinctive activities of the creative entrepreneur (Gielnik et al, 2014). Other scholars (Walton, 2003) find that divergent thinking is not the exclusive component of the entrepreneurial but also "creativity attitudes and interests, personality traits, biographical inventories, and creative accomplishments" are fundamental dimensions.

Moreover, what is interesting is the fact that other scholars (Sternberg and Lubart, 1991; Zohu and Shalley, 2008) identify other components of entrepreneurial creativity belonging to the social and relational sphere (i.e., tem decision making, resources of social network, team dynamics).

The study on the components of entrepreneurial creativity is fundamental for the understanding of what and how the various elements can interplay in this process. It would be interesting to know the weight of each component, if some of them prevail on the others and what are that essential in the composition of entrepreneurial creativity in order to define them as core components. Furthermore, it is important to understand if there are dialectical differences in these papers between antecedents and components of entrepreneurial creativity. Indeed, while 
entrepreneurial creativity antecedents explain the cause-and-effect relationship, the components indicate elements that are part of a set that compose the entrepreneurial creativity. The blatant example is that of Gielnik et al, 2014 and Walton, 2003. Indeed, while the formers identify divergent thinking as antecedent of entrepreneurial creativity, the latter labels it as "factor or dimension" even if it means as factors influencing entrepreneurial creativity. Hence, a more clearness is needed in terms of right classification and explanation.

From this observation a clear gap (Gap 2.1) comes out: Literature on entrepreneurial creativity needs of more contributions, both in quantitative and qualitative terms, focusing on its components. The lack of a clear and complete framework contemplating the individual, organizational and relational components of entrepreneurial creativity leads to the development of new contributions on this focus in order to study the components according to a theoretical and empirical perspective.

Among the total of analysed papers, what is interesting to notice is the fact that 22 papers adopt an overlapping perspective as regards the focus of analysis.

The bar chart (figure 3) shows the number of papers and the overlapping categories. Seven papers deal with the process of entrepreneurial creativity and the cognitive/affective ( $\mathrm{P}+\mathrm{C} / \mathrm{A})$ factors because scholars (Gilad, 1984; Baron et al. 2011), looking at entrepreneurial creativity as a process, find that the cognitive activity is one of the most important during the decision making phase.

Four papers overlap the focus of cognitive/affective factors with the components $(C / A+C)$ of entrepreneurial creativity. This overlapping is due to the fact that cognitive/affective factors are both considered as components of the entrepreneurial creativity (Walton, 2003; Gemmel et al., 2012)

Papers (three papers) regarding both the process and the origins/antecedents $(\mathrm{P}+\mathrm{O})$ explore the connection between the entrepreneurial process and its antecedents.

Other papers (two papers for each of the following identified categories of overlapping), that create the overlapping, refer to the origin/antecedents and the cognitive affective factors $(\mathrm{O}+\mathrm{C} / \mathrm{A})$, process and components of entrepreneurial creativity $(\mathrm{P}+\mathrm{C})$, process, origin/antecedent and cognitive affective factors $(\mathrm{P}+\mathrm{O}+\mathrm{C} / \mathrm{A})$.

The overlapping categories, such as origin/antecedents and components of entrepreneurial creativity $(\mathrm{O}+\mathrm{C})$ and process, cognitive/affective factors and components of entrepreneurial creativity show $(\mathrm{P}+\mathrm{C} / \mathrm{A}+\mathrm{C})$ an underestimated attention by scholar operating in this field.

As it emerged, the overlapping perspective allows to better understand the interrelated focuses of research but literature must direct its efforts towards a clearest analysis of the existing connections. In other words, contributions need of the explicit declare what kind of overlapping they intend to analyse because the existing papers miss of this link.
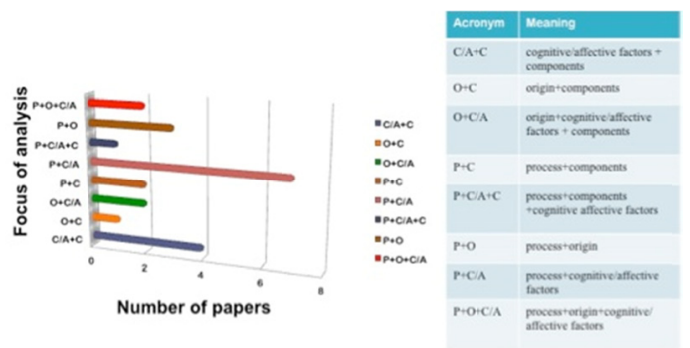

Figure 3. Bar chart on the overlapping focuses of analysis

As regards the theme of entrepreneurial creativity and the main topics, the analysed papers are so distributed: the $60 \%$ are linked with the topic of entrepreneurial opportunities, the $28 \%$ of papers shows a connection between entrepreneurial creativity and the social network, the $6 \%$ of the papers are connected with the topic of entrepreneurial bisociation, with the $5 \%$ with other topics. 


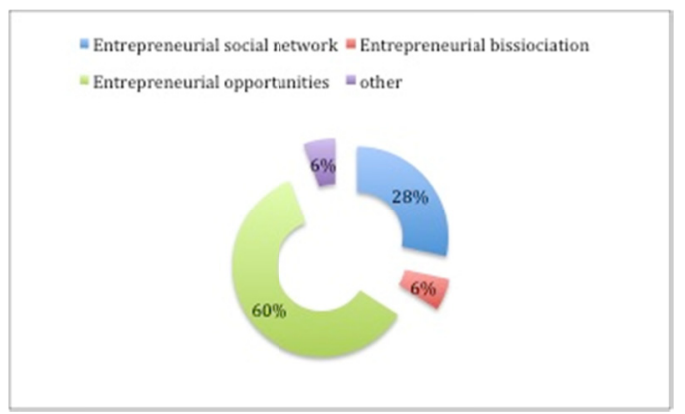

Figure 4. Main topics connected with the theme of entrepreneurial creativity

With reference to the connection between the theme of entrepreneurial creativity and he topic of entrepreneurial opportunities, some scholars (Schumpeter, 1942; Shane and Venkatraman, 2000) stress that the changing context in which the entrepreneur operates influences its perception of opportunities in relation to the firm's resources. Therefore, creativity acquires a double soul: in respect of the external context (soothsaying, spirit of inventiveness) and of the firms' bundles of resources (resources creation, combination and recombination, authoritativeness and leadership, managerial fiat).

Filipczak (1997) underlines the importance for a firm to be made-up by both adaptive and innovative creative individuals. The former have specific skills in reworking existing ideas while the latter implement new and different ideas from existing ones. All these aspects depend on the entrepreneur's risk-taking approach and on his capabilities to innovate.

Alvarez and Busenitz (2001) study the concept of entrepreneurial recognition, which is the capability of recognizing opportunities and of neutralizing threats (heuristics, that is the capacity of exemplifying the complexity of the external context as well as of seeing what others cannot), combined with the process of resources' combinations, recombination and change (Wright et al., 2001). These concepts are not so new, since Knight (1921:348), on this regard, puts into evidence that "it would doubtless be possible to use all the resources of society with more or less effect in reducing uncertainty, leaving none for any other use." Dimov (2007:719) states that "when present and future are separated by fundamental uncertainty, the ex post characteristics of an opportunity cannot be known or correctly perceived ex ante".

Very interesting appears, in this direction, the contribution by McMullen and Shepherd (2006) who focus on two main concepts: the entrepreneur's perception of the level of uncertainty (ability to absorb uncertainty) and the entrepreneurs' capability to operate effectively in uncertain environments (ability to bear uncertainty). In this direction, Butler et al. (2010, p. 125) propose the concept of "uncertainty absorption" bound to the consideration that "the entrepreneur sees associations that allow him to "rationally" see an opportunity unseen by most other observers who lack entrepreneurial insights". The proposed theoretical model refers to the entrepreneurs' capability of noticing opportunities (that is a cognitive perspective) rather than of creating new opportunities. This ambiguity has conducted many scholars to focus on the theme of opportunities. "Opportunities can be represented as a stream of continuously developed ideas, driven and shaped by one's social interaction, creative insights, and action at each stage" (Dimov, 2007, p. 714).

With reference to the connection between entrepreneurial opportunity and entrepreneurial social network, Woodman and Schoenfeldt (1990) concentrate on the contextual and social influences, considering the former connected with the task conditions of the single person, while the latter as bound to the wider social interactions with several stakeholders. Of course, ideas are connected with intuition, which can be defined as "the preconscious recognition of the pattern and/or possibilities inherent in a personal stream of experience" (Weick, 1995). That is the process through which becoming aware that a business idea is perceived to have the potential to meet actual or potential customer needs (Dutta and Crossan, 2005). Dimov (2007) specifies that the context - job situation, available information - can influence the set of hints an individual can get in generating new ideas.

Over time, this approach led scholars to concentrate on the link between creativity, innovation and environmental variables, according to different perspectives: collaboration opportunities and leadership (Bullinger et al., 2004; Howell and Boies, 2004). Collaborations can sometimes result in the development and integration of complementary competencies which impact on creativity. The climate, or people's perceptions of their work environment in terms of factors such as support and autonomy, can have an impact on creativity (Anderson, 1998; 


\section{West, 2002).}

The social network the individual is embedded in can significantly influence the idea generation as well as the perception of its feasibility through the interaction with other individuals (Greve and Salaff, 2003), representing an important antecedent to entrepreneurial creativity (Perry-Smith, 2006) and can have a positive impact on the creative context (Schoenfeldt, 1989). Such view enlarges the perspective from the single individual with his/her own intrinsic features to a complex unit of analysis, made of a network of relationships that can influence the process of idea generation and perception of its feasible implications.

As regards the link between entrepreneurial creativity and bisociation, very interesting appears Koestler's (1964) view, which considers at the basis of creativity the concepts of counterarguments - bisociation - in terms of result of two different frames of thinking.

From here, the connection between creativity and ambidexterity comes out, since the creative entrepreneur can run contradictory situations or, in other words, "connecting the dots where the links are not obvious" (Ko \& Butler, 2007, p. 369).

Even if this view was not referred to entrepreneurship, it has been successively applied to the context, as confirmed by some definitions (Amabile, 1997) in which creativity is conceived as the "generation of novel and appropriate solutions to open-ended problems in any domain of human activity" (Ko \& Butler, 2007, p. 367). Such view challenges the trade-off between novelty and usefulness (Hargadon \& Douglas, 2001). On this topic, some authors (Ford \& Sullivan, 2004) assert that in organizational project teams novelty is represented by an S-shape since the useful of novelty decreases as the project advances. In a different perspective, Lichfield (2008) explains that novel ideas can take a higher time to become useful in their implementation, owing to their own novelty and difficulty in interacting with organizational routines. In this optic, if creativity is made of novelty and usefulness, its management could be that of novelty and of usefulness goals.

The above-described interconnections (Figure 4) between the theme of entrepreneurial creativity and the main topics (entrepreneurial social network, entrepreneurial bisociation, entrepreneurial opportunities) highlight the exploratory soul of this literature review because it underlines the current debate and shows the main interrelated topics. The other soul, the confirmatory one, allows to identify the research gaps and to verify if the current research has achieved satisfactory results.

First of all, as regards the topic entrepreneurial opportunities, it is important to underline a limitation of existing approaches to opportunity identifications/creation, since the heterogeneity of entrepreneurs is not taken into account. Differences in background and experience can lead entrepreneurs to differences in innovative opportunity identification/creation. Hence, further works must focus the attention on how and to what extent the entrepreneurs' personal background can influence the opportunity identification/creation. To this, it is necessary to add the issue of stable/turbulent environment in which opportunities can be caught and/or created.

Secondly, as regards the social network, contributions limit their focus on the single individual rather than explore the opportunities arising from the network. Other scholars extend this view, stating that entrepreneurs who are networked to opportunity sources may even not need to be as creative as those who are not networked, since their creativity is linked to that of others in the network (Hills et al., 1997). Furthermore, it would be interesting to understand if the recourse to social network or the influence of social network on the entrepreneurial creativity in what stage occurs (i.e., new business venturing, development phase, etc.).

Thirdly, the topic of bisociation is underanalyzed as the percentage (6\%) demonstrates. Hence, literature efforts must pause on the study of this precise process, the different frames that can interplay and how the synthesis between divergent thinking happens.

The systematic literature review also takes into account the methodologies adopted in the analysed papers. The majority of contributions ( 35 papers) uses theoretical with application, followed by conceptual papers that we label literature review ( 32 papers), comparative study (12 papers), survey (5 papers) and case study (4 papers). This allocation shows the clear necessity to direct future research on case study methodology, also in the comparative form, in order to understand what it emerges from the analysis and if there are significant differences, for example among the entrepreneurs that operate in the same sector or different sectors. 


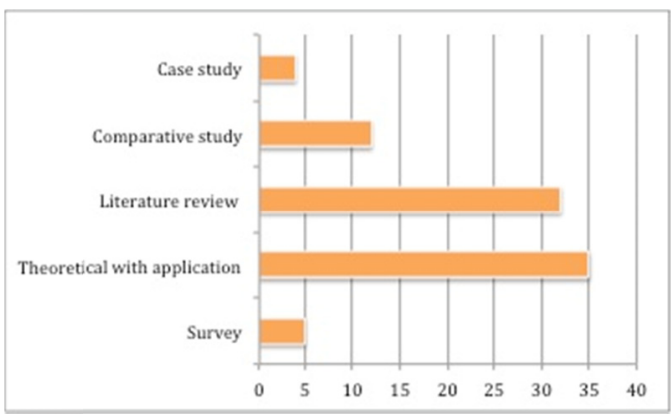

Figure 5. Adopted methodologies

Table 3. List of top five journals

\begin{tabular}{ll}
\hline Journal & Number of papers \\
\hline The Journal of creative behavior & 11 \\
Creativity and Innovation Management & 9 \\
Strategic Entrepreneurship Journal & 7 \\
Journal of Small Business Management & 5 \\
Journal of Business Venturing & 4 \\
\hline
\end{tabular}

As regards the stream of research, we recall the classification made by Campos et al (2012). More precisely, 2 papers refer to economics and entrepreneurship stream of research, nine papers to education and entrepreneurship, twelve papers to new business/technology and entrepreneurship, fourteen papers to psychology, eleven papers to sociology and teams, forty papers to strategic entrepreneurship. According the classification of Campos et al (2012), none paper focuses the attention on ethnic and social entrepreneurship stream of research.

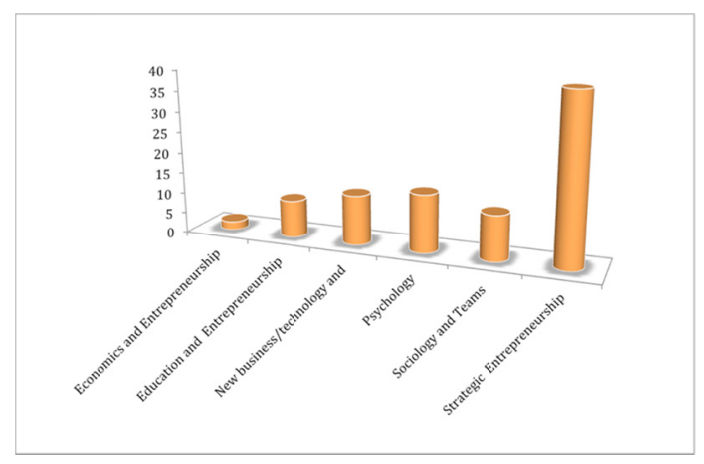

Figure 6. Streams of research

What is important to notice is the fact that Ward (2004) analyses creative entrepreneurship from a psychological point of view, achieving specific cognitive, personal and social constructs.

Studies on personality focus on biographical characteristics of creative individuals and on their activities (Woodman and Schoenfeldt, 1990). These works aim at the identification of possible creative behaviours of both individuals and organizations. Some authors concentrate on "creative entrepreneurial competencies and philosophies", based on self-belief and ambition, capability of building relationships in creative networks, high motivation, communication skills, problem-solving, flexibility, capacity of breaking down both physical and perceptual barriers (Fillis, 2004; Petrowski, 2000). Positive traits of creativity also include open-mindedness in facing both uncertainty and ambiguity (Feist, 1999). However, many of these characteristics are also typical of entrepreneurship in general (Barron and Harrington, 1981:453).

Anyway, the studies based on the research and analysis of personal traits show a lack of longitudinal approach. It would be interesting to monitor the identified entrepreneurial characteristics over time to understand how and to what extent these latters could differently influence creativity. 


\section{Conclusions}

By the analysis of the selected papers, some interesting hints for conclusion come out. Based on the literature recognition, this study addresses several issues, one of which is the comprehension of the possible disconnection between the creative insight and the idea implementation, which, instead, should represent a basic condition for creative entrepreneurship. This aspect is underlined both in the contributions referred to the creativity as a process and to the theme of creating and catching opportunities. More precisely, the link between the generation of ideas and its implementation is not obvious: it is influenced by the unpredictability of the external context in which the entrepreneurs operate. This opens to wide research advances.

Although Bratnicka and Bratnicki (2013) underline that creativity requires both creation and selection of alternatives, there is a clear lack of connection with the following step referring to the implementation of selected ideas and therefore of the holistic perspective on the whole process. Nonetheless, it is important to underline that even if the entrepreneur possesses the creative competencies cited in the psychological contributions, this does not necessarily lead to an effective and practical outcome. On the other side, some studies (Fillis and Rentschler, 2010; Zhou, 2008) focusing the attention on the process, take the generation of ideas for granted. In line with Zampetakis et al's (2010) thought, creative ideas must be monitored as their remoteness can influence in different ways the organizational outcome. It is also important to understand whether and how literature analyzes the lapse of time between the generation of ideas and its effective implementation. Indeed, in the same direction Dimov (2007:718) underlines that "it is not about the idea per se; rather, it is about finding out whether the idea can really deliver its original promise".

As regards the definition of entrepreneurial creativity, Perry-Smith and Coff (2011) and Phan and Zou (2011) define it as an antecedent to entrepreneurial discovery (Phan and Zhou, 2010); others as an entrepreneurial characteristic (Butler et al, 2010), still others as an essential component in the entrepreneurship process (Zhou, 2008). Some scholars link the creativity to a flexible approach necessary for the entrepreneurial challenges (Fillis and Rentschler, 2010) that creates alternative solutions. A final definition of entrepreneurial creativity is therefore the capability of creating and catching opportunities as well as of creating, recombining and/or using firms ' resources differently - in new ways. This definition encloses the bisociative capability in seeing how new opportunities and resources can foster the firm's competitive advantage and the connected created value.

Our analysis of prior studies shows that entrepreneurial creativity is also an attitude and it is, sometimes associated with innovative flexibility (Fillis, 2007; Baron and Tang, 2011) and strategic elasticity, as synonymous of creativity. Finally, even if creativity is necessarily expected to come from the entrepreneur, this latter should be also able to spread it at each organisational level in order to achieve a practical improvement in the firm's performance.

From the above-explained concepts, some interesting hints for future research come out. First, it is interesting to focus on the differences and links between creativity, innovative flexibility (changing strategies - Baron and Tang, 2011) and strategic elasticity (enlarging the set of opportunities for the firm, either caught or created). This topic is still closed to Barney's concept of strategic factor markets (1986) in terms of its strategic implications. It could be interesting to verify if creativity itself is a strategic factor market. Secondly, the literature review reveals that the majority of works $(52 \%)$ concentrate the attention on process rather than on the individual factors. This result is in line on what underlines Dyan et al (2013) underline when they claim that "little research has investigated that intrinsic motivation mediates effects of individual related factors on creativity". Indeed, future research must concentrate the attention on the individual factors that not only influence but also contribute to sustain entrepreneurial creativity.

The literature review demonstrates that $52 \%$ of the papers concentrate the attention on the process, the $23 \%$ on the antecedents, the $15 \%$ on the cognitive/affective factors and the $10 \%$ on the main components of the entrepreneurial creativity.

Besides, more work is required, considering that "perhaps the main deficiency of this line of research is the conceptual collapse of the time between a first insight and the idea that ends up being implemented" (Dimov, 2007, p. 717). "It is not about the idea per se; rather, it is about finding out whether the idea can really deliver its original promise" (p.718).

Even if in the literature, different studies underline the difference between catching and creating opportunities (Alvarez \& Barney, 2007) there is still a lack in empirical findings that prove the effectiveness of such difference. Our hint is that this might be a false problem, even if we know that many scholars on the fill will be disappointed about this. The point is that if creativity is somewhat a capability in the organization, at any level of the structure, it may consist of both or of only one of them, but this does not mean it is not creativity. A good decision maker 
or an intuitive employee may see outside something other do not or may create a totally new, crazy idea that has some potential for implementation. Does this different really matter? From this point of view, an analysis through dynamic capabilities perspective (Della Corte \& Del Gaudio, 2012) may be interesting, since it is a dynamic capability referred to any level of the firm's overall human capital.

In such direction, some more clearness appear necessary on the debate between epistemological and ontological nature of creativity, considering that Dimov (2007:724) asserts that "while silent to their ontological aspect - who would deny that a physical reality exists out there? - it highlights their epistemological aspect, i.e., the interpretation and meaning that people have of this underlying reality". There is a subtle transition from the idea to opportunities, because if creativity regards idea generation, entrepreneurship is practical shaping into business decision making. This takes to the last but not least aspect to underline: the issue of implementation, since one of the most interesting aspects is how the idea is translated into practical actions. Most of studies that, as said, are concentrated on the process, just explain that after the idea generation there is the implementation phase. But one of the most important challenges for us as scholars in entrepreneurship is giving answers and suggestions to the real world on how ideas are converted into practice, how strategic change is carried out and what are the main criticalities and results of such processes. This latter is still a real black box probably in the wider area of strategic management.

\section{References}

Alvarez, S. A., \& Barney, J. B. (2007). Discovery and creation: Alternative theories of entrepreneurial action. Strategic Entrepreneurship Journal, 1(1-2), 11-26. doi10.1002/sej.4

Alvarez, S. A., \& Busenitz, L. W. (2001). The entrepreneurship of resource-based theory. Journal of Management, 27, 755-775.

Amabile, T. M. (1997). Entrepreneurial creativity through motivational synergy. The Journal of Creative Behavior, 31, 18-26. doi10.1177/014920630102700609

Amabile, T. M., Barsade, S. G., Mueller, J. S., \& Staw, B. M. (2005). Affect and creativity at work. Administrative Science Quarterly, 50(3), 367-403.

Anderson, A. R. (1998) Cultivating the Garden of Eden: environmental entrepreneuring. Journal of Organizational Change Management, 11(2), 135-144. http://dx.doi.org/10.1108/09534819810212124

Anderson, A., Dodd, S. D., \& Jack, S. (2009). Aggressors; Winners; Victims and Outsiders European Schools' Social Construction of the Entrepreneur. International Small Business Journal, 27(1), 126-136.

Antonites, A. J., \& Van Vuuren, J. J. (2014). Inducing entrepreneurial creativity, innovation and opportunity-finding skills. South African Journal of Economic and Management Sciences, 8(3), 255-271.

Ardichvili, A., Cardozo, R., \& Ray, S. (2003). A theory of entrepreneurial opportunity identification and $\begin{array}{lllll}\text { development. Journal of Business } & \text { 105-123. }\end{array}$ http://dx.doi.org/10.1016/S0883-9026(01)00068-4

Barney, J. B. (1986). Strategic factor markets: Expectations, luck, and business strategy. Management science, 32(10), 1231-1241. http://dx.doi.org/10.1287/mnsc.32.10.1231

Baron, R. A., \& Tang, J. (2011). The role of entrepreneurs in firm-level innovation: Joint effects of positive affect, creativity, and environmental dynamism. Journal of Business Venturing, 26(1), 49-60. http://dx.doi.org/10.1016/j.jbusvent.2009.06.002

Barron, F., \& Harrington, D. M. (1981). Creativity, intelligence, and personality. Annual Review of Psychology, 32(1), 439-476. doi10.1146/annurev.ps.32.020181.002255

Blauth, M., Mauer, R., \& Brettel, M. (2014) Fostering creativity in new product development through entrepreneurial decision making. Creativity and Innovation Management, 23(4), 495-509. doi10.1111/caim.12094

Block, J. H., Thurik, R., \& Zhou, H. (2013). What turns knowledge into innovative products? The role of entrepreneurship and knowledge spillovers. Journal of Evolutionary Economics, 23(4), 693-718. http://dox.doi.org/10.1007/s00191-012-0265-5

Brady, J. E., \& Allen, T. T. (2006). Six Sigma literature: a review and agenda for future research. Quality and reliability engineering International, 22(2), 335-367. http://dx.doi.org/10.1002/qre.769

Bratnicka, K., \& Bratnicki, M. (2013). Linking two dimensions of organizational creativity to firm performance: the mediating role of corporate entrepreneurship and the moderating role of environment. Advances in 
Business-Related Scientific Research Journal, 4(2), 153-163.

Bullinger, H. J., Auernhammer, K., \& Gomeringer, A. (2004). Managing innovation networks in the knowledge-driven economy. International Journal of Production Research, 42(17), 3337-3353. http://dx.doi.org/10.1080/00207540410001695970

Butler, J. E., Doktor, R., \& Lins, F. A. (2010). Linking international entrepreneurship to uncertainty, opportunity discovery, and cognition. Journal of International Entrepreneurship, 8(2), 121-134. http://dx.doi.org/10.1007/s10843-010-0054-x

Carnahan, S., Agarwal, R., Campbell, B. A., \& Franco, A. (2010). The Effect of Firm Compensation Structures on Employee Mobility and Employee Entrepreneurship of Extreme Employers. US Census Bureau Center for Economic Studies Paper No. CES-WP-10-06.

Csikszentmihalyi, M. (1996) Creativity. New York: USA. HarperCollin.

Dasgupta, S. (1994). Creativity in Invention and Design. New York. NY: USA: Cambridge University Press.

Dayan, M., Zacca, R., \& Di Benedetto, A. (2013). An Exploratory Study of Entrepreneurial Creativity: Its Antecedents and Mediators in the Context of UAE Firms. Creativity and Innovation Management, 22(3), 223-240. http://dx.doi.org/10.1111/caim.12036

Delgado - García, J. B., Rodríguez - Escudero, A. I., \& Martín - Cruz, N. (2012). Influence of affective traits on entrepreneur's goals and satisfaction. Journal of Small Business Management, 50(3), 408-428. http://dx.doi.org/10.1111/j.1540-627X.2012.00359.x

Della Corte, V., \& Del Gaudio, G. (2012). Dynamic capabilities: a still unexplored issue with growing complexity. Corporate Ownership \& Control, 9(4), 327-339.

Dijksterhuis, A., \& Meurs, T. (2006).Where creativity resides: The generative power of unconscious thought. Consciousness and cognition, 15, 135-146. http://dx.doi.org/10.1016/j.concog.2005.04.007

Dimov, D. (2007). Beyond the single-person, single-insight attribution in understanding entrepreneurial opportunities. Entrepreneurship Theory and Practice, 31(5), 713-731. 10.1111/j.1540-6520.2007.00196.x

Dutta, D. K., \& Crossan, M. M. (2005). The nature of entrepreneurial opportunities: understanding the process using the 4I organizational learning framework. Entrepreneurship Theory and Practice, 29(4), 425-449. $10.1111 / \mathrm{j} .1540-6520.2005 .00092 . \mathrm{x}$

Eckhardt, J. T., \& Shane, S. A. (2003). Opportunities and entrepreneurship. Journal of Management, 29(3), 333-349.

Feist, G. J. (1999). The Influence of Personality on Artistic and Scientific Creativity. In R. J. Sternberg (Ed.), Handbook of Creativity. Cambridge. CA: USA: Cambridge University Press.

Filipczak, B. (1997) It Takes All Kinds: Creativity in the Work Force. Training, 34, 32.

Fillis, I. (2007). A methodology for researching international entrepreneurship in SMEs: A challenge to the status quo. Journal of Small Business and Enterprise Development, 14(1), 118-135. http://dx.doi.org/10.1108/14626000710727935

Fillis, I., \& Rentschler, R. (2010). The role of creativity in entrepreneurship. Journal of Enterprising Culture, 18(1), 49-81. http://dx.doi.org/10.1142/S0218495810000501

Ford, C., \& Sullivan, D. M. (2004). A time for everything: How the timing of novel contributions influences project team outcomes. Journal of Organizational Behavior, 25(2), 279-292. http://dx.doi.org/10.1002/job.241

Fortwengel, J., Schüßler, E., \& Sydow, J. (2016). Studying Organizational Creativity as Process: Fluidity or Duality? Creativity and Innovation Management, 26(1), 5-16. http://dx.doi.org/doi10.1111/caim.12187

Frodeman, R. (2014). Transdisciplinarity as Sustainability. In K. Huutoniemi \& P. Tapio (Eds.), Transdisciplinary Sustainability Studies: A Heuristic Approach. London: UK.

Gemmell, R. M., Boland, R. J., \& Kolb, D. A. (2012). The socio-cognitive dynamics of entrepreneurial ideation. $\begin{array}{llll}\text { Entrepreneurship Theory } \quad \text { and } & \text { Practice, }\end{array}$ http://dx.doi.org/10.1111/j.1540-6520.2011.00486.x

George, J. M., \& Zhou, J. (2007) Dual tuning in a supportive context: Joint contributions of positive mood, negative mood, and supervisory behaviors to employee creativity. Academy of Management Journal, 50(3), 
605-622. http://dx.doi.org/10.5465/AMJ.2007.25525934

Gielnik, M. M., Krämer, A. C., Kappel, B., \& Frese, M. (2014). Antecedents of business opportunity identification and innovation: Investigating the interplay of information processing and information acquisition. Applied Psychology, 63(2), 344-381. http://dx.doi.org/10.1111/j.1464-0597.2012.00528.x

Gilad, B. (1984). Entrepreneurship: the issue of creativity in the market place. The Journal of Creative Behavior, 18(3), 151-161. http://dx.doi.org/10.1002/j.2162-6057.1984.tb00379.x

Gong, Y., Huang, J. C., \& Farh, J. L. (2009) Employee learning orientation, transformational leadership, and employee creativity: The mediating role of employee creative self-efficacy. Academy of management Journal, 52(4), 765-778. http://dx.doi.org/10.5465/AMJ.2009.43670890

Goss, B. D., Jubenville, C. B., \& Polite, F. G. (2007) Applying an advertising creativity model to the NFL's black qurterbacks and postmodern sport marketing practices. Marketing Management Journal, 17(1), 65-81.

Greve, A., \& Salaff, J. W. (2003) Social networks and entrepreneurship. Entrepreneurship theory and practice, 28(1), 1-22. http://dx.doi.org/10.1111/1540-8520.00029

Hargadon, A. B., \& Douglas, Y. (2001). When innovations meet institutions: Edison and the design of the electric light. Administrative science quarterly, 46(3), 476-501.

Hattab, H. W. (2014). Impact of entrepreneurship education on entrepreneurial intentions of university students in Egypt. Journal of Entrepreneurship, 23(1), 1-18.

Hills, G. E., Lumpkin, G. T., \& Singh, R. P. (1997) Opportunity recognition: Perceptions and behaviors of entrepreneurs. Frontiers of entrepreneurship research, 17(4), 168-182.

Hornsby, J. S., Kuratko, D. F., \& Zahra, S. A. (2002). Middle managers' perception of the internal environment for corporate entrepreneurship: assessing a measurement scale. Journal of business Venturing, 17(3), 253-273. http://dx.doi.org/10.1016/S0883-9026(00)00059-8

Howell, J. M., \& Boies, K. (2004). Champions of technological innovation: The influence of contextual knowledge, role orientation, idea generation, and idea promotion on champion emergence. The leadership quarterly, 15(1), 123-143. http://dx.doi.org/10.1016/j.leaqua.2003.12.008

Jabani Mambula, C., \& Sawyer, F. E. (2004). Acts of entrepreneurial creativity for business growth and survival in a constrained economy: Case study of a small manufacturing firm (SMF). International Journal of Social Economics, 31(1/2), 30-55. http://dx.doi.org/10.1108/03068290410515402

Jurčová, M. (1996). Slovak Entrepreneurs-Pioneers. Creativity and Innovation Management, 5(2), 134-141. http://dx.doi.org/10.1111/j.1467-8691.1996.tb00133.x

Kijkuit, B., \& Van Den Ende, J. (2007). The Organizational Life of an Idea: Integrating Social Network, Creativity and Decision - Making Perspectives. Journal of Management Studies, 44(6), 863-882. http://dx.doi.org/10.1111/j.1467-6486.2007.00695.x

Knight, F. (1921) Risk, Uncertainty and Profit. Boston: USA: Houghton-Mifflin,

Ko, S., \& Butler, J. E. (2007) Creativity: A key link to entrepreneurial behavior. Business Horizons, 50(5), 365-372. http://dx.doi.org/10.1016/j.bushor.2007.03.002

Koestler, A. (1964). The act of creation: A study of conscious and unconscious processes in humor, scientific discovery and act. New York. USA: The Macmillan Company.

Lee, S. Y., Florida, R., \& Acs, Z. (2004) Creativity and entrepreneurship: A regional analysis of new firm formation. Regional studies, 38(8), 879-891. http://dx.doi.org/10.1080/0034340042000280910

Mahoney, J. T., \& Michael, S. C. (2005). A subjectivist theory of entrepreneurship. Handbook of Entrepreneurship. New York, NY: Springer

McMullen, J. S., \& Shepherd, D. A. (2006). Entrepreneurial action and the role of uncertainty in the theory of the entrepreneur. Academy of Management review, 31(1), 132-152. http://dx.doi.org/10.5465/AMR.2006.19379628

Nyström, H. (1993). Creativity and entrepreneurship. Creativity and Innovation Management, 2(4), 237-242. http://dx.doi.org/10.1111/j.1467-8691.1993.tb00102.x

Perry-Smith, J. E. (2006). Social yet creative: The role of social relationships in facilitating individual creativity. Academy of Management Journal, 49(1), 85-101. http://dx.doi.org/10.5465/AMJ.2006.20785503 
Perry-Smith, J. E., \& Coff, R. W. (2011). In the mood for entrepreneurial creativity? How optimal group affect differs for generating and selecting ideas for new ventures. Strategic Entrepreneurship Journal, 5(3), 247-268. http://dx.doi.org/10.1002/sej.116

Perry-Smith, J. E., \& Shalley, C. E. (2003). The social side of creativity: A static and dynamic social network perspective. Academy of Management Review, 28(1), 89-106. http://dx.doi.org/10.5465/AMR.2003.8925236

Petrowski, M. J. (2000). Creativity research: implications for teaching, learning and thinking. Reference Services Review, 28(4), 304-312. http://dx.doi.org/10.1108/00907320010359623

Phan, P., Zhou, J., \& Abrahamson, E. (2010). Creativity, innovation, and entrepreneurship in China. Management and Organization Review, 6(2), 175-194. http://dx.doi.org/10.1111/j.1740-8784.2010.00181.x

Rahman, H., \& Day, J. (2015) Involving the Entrepreneurial Role Model: A Possible Development for Entrepreneurship Education. Journal of Entrepreneurship Education, 18(1), 86.

Sardana, D. (2015). What Facilitates Cultural Entrepreneurship?-A Study of Indian Cultural Entrepreneurs. The Journal of Creative Behavior, 1-24. http://dx.doi.org/10.1002/jocb.131

Schumpeter, J. (1942). Creative destruction. Capitalism, socialism and democracy. New York, NY: Harper.

Schwarz, N., \& Bless, H. (1991) Happy and mindless, but sad and smart? The impact of affective states on analytic reasoning, Emotion and social judgments. Oxford, USA: Pergamon.

Scratchley, L. S., \& Hakstian, A. R. (2001). The measurement and prediction of managerial creativity. Creativity Research Journal, 13(3-4), 367-384. http://dx.doi.org/10.1207/S15326934CRJ1334_14

Shalley, C. E., \& Perry-Smith, J. E. (2008). The emergence of team creative cognition: the role of diverse outside ties, sociocognitive network centrality, and team evolution. Strategic Entrepreneurship Journal, 2(1), 23-41. http://dx.doi.org/10.1002/sej.40

Shane, S., \& Venkataraman, S. (2000). The promise of entrepreneurship as a field of research. Academy of Management Review, 25(1), 217-226. http://dx.doi.org/10.5465/AMR.2000.2791611

Shepherd, D. A., \& Patzelt, H. (2011). The new field of sustainable entrepreneurship: studying entrepreneurial action linking "what is to be sustained" with "what is to be developed". Entrepreneurship Theory and Practice, 35(1), 137-163. http://dx.doi.org/10.1111/j.1540-6520.2010.00426.x

Sternberg, R. J. (1999). Handbook for Economic Studies Paper, CES-WP, 10-06 creativity. Cambridge, UK: University Press, Cambridge,

Sullivan, D. M., \& Ford, C. M. (2010). The alignment of measures and constructs in organizational research: The case of testing measurement models of creativity. Journal of Business and Psychology, 25(3), 505-521. http://dx.doi.org/10.1007/s10869-009-9147-8

Villalba, E. (2010). Monitoring Creativity at an Aggregate Level: a proposal for Europe. European Journal of Education, 45(2), 314-330. http://dx.doi.org/10.1111/j.1465-3435.2010.01431.x

Ward, T. B. (2004). Cognition, creativity, and entrepreneurship. Journal of business venturing, 19(2), 173-188. http://dx.doi.org/10.1016/S0883-9026(03)00005-3

Weick, K. E. (1995). Sensemaking in Organizations. Thousand Oaks, CA: Sage Publications,

West, M. A. (2002). Sparkling fountains or stagnant ponds: An integrative model of creativity and innovation implementation in work groups. Applied psychology, 51(3), 355-387.doi 10.1111/1464-0597.00951

Winslow, C. M., Solomon, D. H., Chassin, M. R., Kosecoff, J., Merrick, N. J., \& Brook, R. H. (1988). The appropriateness of carotid endarterectomy. New England Journal of Medicine, 318(12), 721-727. http://dx.doi.org/10.1056/NEJM198803243181201

Woodman, R. W., and Schoenfeldt, L. F. (1990). An interactionist model of creative behavior. The Journal of Creative Behavior, 24(1), 10-20. http://dx.doi.org/10.1002/j.2162-6057.1990.tb00525.x

Zain, Z. M., Dale, B. G., \& Kehoe, D. F. (2001). Total quality management: an examination of the writings from a UK perspective. The TQM Magazine, 13(2), 129-137. http://dx.doi.org/10.1108/09544780110366051

Zampetakis, L. A., Bouranta, N., \& Moustakis, V. S. (2010). On the relationship between individual creativity and time management. Thinking Skills and Creativity, 5(1), 23-32. http://dx.doi.org/10.1016/j.tsc.2009.12.001

Zhou, J. (2008). New look at creativity in the entrepreneurial process. Strategic Entrepreneurship Journal, 2(1), 1-5. http://dx.doi.org/10.1002/sej.38 


\section{Copyrights}

Copyright for this article is retained by the author(s), with first publication rights granted to the journal.

This is an open-access article distributed under the terms and conditions of the Creative Commons Attribution license (http://creativecommons.org/licenses/by/4.0/). 